CLINICAL STUDY

\title{
Soluble CTLA-4 receptor an immunological marker of Graves' disease and severity of ophthalmopathy is associated with CTLA-4 Jo31 and CT60 gene polymorphisms
}

\author{
Jacek Daroszewski, Edyta Pawlak ${ }^{1}$, Lidia Karabon ${ }^{1}$, Irena Frydecka ${ }^{1,2}$, Anna Jonkisz ${ }^{3}$, Miroslaw Slowik ${ }^{4}$ \\ and Marek Bolanowski \\ Department of Endocrinology, Diabetology, and Isotope Therapy, Medical University, ul. Pasteura 4, 50-367 Wroclaw, Poland, ${ }^{1}$ Laboratory of \\ Immunopathology, Department of Experimental Therapy, Institute of Immunology and Experimental Therapy, Polish Academy of Sciences, ul. Weigla 12, \\ 53-114 Wroclaw, Poland, ${ }^{2}$ Department of Hematology, Blood Neoplastic Diseases, and Bone Marrow Transplantation, Medical University, ul. Pasteura 4, \\ 50-367 Wroclaw, Poland, ${ }^{3}$ Department of Forensic Medicine, Medical University, ul. Curie-Sklodowskiej, 52, 50-368 Wroclaw, Poland and ${ }^{4}$ Department \\ of Ophthalmology, Medical University, ul. Chalubinskiego 2a, 50-368 Wroclaw, Poland \\ (Correspondence should be addressed to E Pawlak; Email: epawlak@iitd.pan.wroc.pl)
}

(J Daroszewski and E Pawlak contributed equally to this work)

\begin{abstract}
Objective: Graves' disease (GD) is an autoimmune disorder with genetic and environmental background. CTLA-4 is a candidate gene for thyroid autoimmunity. Increased serum levels of soluble CTLA-4 (sCTLA-4) were found in some autoimmune diseases.

Aim: The aim of the study was to evaluate the relation between sCTLA-4 level and clinical manifestation of Graves' ophthalmopathy (GO), thyroid status, and CTLA-4 gene polymorphisms.

Design: Serum sCTLA-4 concentrations were determined in 93 GO patients and 93 healthy controls. In the GO group, CTLA-4 gene was genotyped in five polymorphic sites: g.319C > T, c.49A $>$ G, CT60 by means of PRC-RFLP, Jo31, and g.*642AT(8_33) by means of minisequencing assay.

Results: Serum sCTLA-4 level was significantly higher in the GO group than in controls (median: 7.94 vs $0.00 \mathrm{ng} / \mathrm{ml}, P=0.000001$ ). This level was higher in severe than in nonsevere GO (median: 10.3 vs $5.6 \mathrm{ng} / \mathrm{ml}, P=0.01)$. sCTLA-4 concentration was related neither to the activity of GO nor to thyroid function. Elevated sCTLA-4 levels were observed in carriers Jo31[G] allele (genotype GG+GT) as compared with subjects with an absence of the [G] allele (TT genotype; median: $9.18 \mathrm{vs} 4.0 \mathrm{ng} / \mathrm{ml}$, $P=0.02$ ). Also patients possessing CT60[G] allele (genotype GG+GA) had higher serum sCTLA-4 levels than subjects who lack the [G] allele (AA genotype; median: $8.73 \mathrm{vs} 2.28 \mathrm{ng} / \mathrm{ml}, P=0.03$ ). Conclusions: It was shown for the first time that increased serum concentration of sCTLA-4 correlate with the severity of GO. Genetic variation in the CTLA-4 gene region in GD patients at least partially determines the level of sCTLA-4.
\end{abstract}

European Journal of Endocrinology 161 787-793

\section{Introduction}

Graves' disease (GD) is an organ-specific autoimmune multifactorial disease that develops as a result of complex interaction between genetic susceptibility genes and environmental factors (1-6). GD is characterized immunologically by a lymphocytic infiltrate of the thyroid and by evidence of immune system activation, with an increased number of circulating $\mathrm{T}$ lymphocytes and levels of thyroid-specific antibodies, mimicking TSH action and thus causing hyperthyroidism (1-4). Graves' ophthalmopathy (GO) is an extrathyroidal manifestation of GD. In $5-10 \%$ of patients, eye symptoms occur in severe stage and require an intensive treatment.

The CD80/CD86/CD28/CTLA-4 co-stimulatory pathway is important in the pathogenesis of autoimmune diseases (7). The cytotoxic $\mathrm{T}$ lymphocyte antigen-4 (CTLA-4) molecule plays a key role in the maintenance of peripheral tolerance as well as termination of T-cell responses $(8,9)$.

Apart from the membrane CTLA-4 molecule, an alternate transcript of CTLA-4 mRNA that encodes a protein lacking a transmembrane region, which likely represents a native soluble form of CTLA-4 (sCTLA-4), has recently been described (10-12). Native sCTLA-4 possesses binding ability to $\mathrm{CD} 80 / \mathrm{CD} 86$, but the immunological effects mediated by endogenous sCTLA-4 have not yet been clarified (11-13). It is suggested that SCTLA- 4 can act as a competitor of CD28 to bind CD80 or CD86, thereby interfering with T-lymphocyte activation in the initiation of immune response (14).

Studies of serum sCTLA-4 levels in autoimmune disease are still very limited. The CTLA-4 isoform is 
observed significantly more often in patients with generalized autoimmune disorders, such as systemic lupus erythematosus (15), systemic sclerosis (16), multiple sclerosis (17), and organ-specific diseases such as type 1 diabetes (18-20). Studies performed for sCTLA-4 isoform level in sera in myasthenia gravis gave inconsistent results (21-23). In Hashimoto's thyroiditis, a high sCTLA-4 concentration seems to be firmly confirmed, but data regarding GD are limited $(11,13)$. Recently, some data regarding the association of CTLA-4 gene polymorphisms with circulating sCTLA-4 level in serum, were presented $(15,18-21,24,25)$.

In this study, we reported data on SCTLA-4 concentrations in patients with different stages of GD accompanied by ophthalmopathy. The results were compared with regard to thyroid status and the clinical manifestation of GO. We also assessed the correlation between the serum SCTLA-4 levels and CTLA-4 gene polymorphisms. To the best of our knowledge, no data describing the association of serum sCTLA-4 levels and thyroid function, clinical presentation of GO in the large cohort as well as the association of CTLA-4 gene polymorphisms g.319C $>\mathrm{T}$, c.49A $>\mathrm{G}$, CT60, Jo31, and g. ${ }^{*} 642 \mathrm{AT}\left(8 \_33\right)$ and sCTLA-4 in GD and GO were reported to date.

\section{Materials and methods}

\section{Subjects}

Ninety-three patients suffering from GO (76 females and 17 males, mean age: 50.0 \pm 11.7 years, range: $20-82$ years) were enrolled into the study. The initial diagnosis of GD was based on clinical and laboratory tests, including a history of thyrotoxicosis, diffuse goiter, suppressed serum TSH, elevated free thyroxine $\left(\mathrm{fT}_{4}\right)$, and/or free triiodothyronine $\left(\mathrm{fT}_{3}\right)$ levels, as well as high anti-thyroid peroxidase (anti-TPO) or TSH-binding inhibiting immunoglobulin (TBII) titers. Twenty-eight patients were euthyroid, while 48 were hyperthyroid and 17 were hypothyroid at the time of serum collection. Nineteen patients had been treated with radioiodine ${ }^{131} \mathrm{I}$; the time since the isotope application ranged from 18 to 92 months. None of the patients had remarkable co-morbidities. History of thyroid diseases in first-line relatives as well as current smoking status was recorded.

The control group consisted of 93 apparently healthy volunteers (staff members) originating from the same geographical area as the patients. There were 33 women and 60 men, aged between 18 and 56 years (mean: 48.2 \pm 7.9 ). In controls, sCTLA-4 serum level, but not CTLA-4 gene polymorphisms, was assessed.

The local ethics committee approved the study protocol, and all patients and controls gave their informed consent for the study procedure.

\section{Assessment of ocular changes}

Ophthalmological examination was performed at the time of blood collection. The severity of ophthalmopathy was assessed using criteria given by Bartalena et al. $(26,27)$ taking into account the degree of proptosis, diplopia, and optic neuropathy (Table 1). Twenty-one patients presented a mild, 21 patients a moderate, and 51 patients a severe degree of eye symptoms. The patients were divided into two groups: with nonsevere eye symptoms (mild and moderate GO) and with severe GO (Table 2). Ophthalmopathy was also scored using an ophthalmopathy index based on the NOSPECS classification (28). The activity of GO was assessed by means of a numerical clinical activity score (CAS), originally described by Mourits et al. (29).

\section{DNA preparation}

Genomic DNA was prepared from peripheral white blood cells using a QIAamp DNA Blood Mini Kit (Qiagen GmbH, Hilden, Germany).

\section{Genotyping/determination of polymorphisms}

The polymorphisms g.319C $>\mathrm{T}$ (rs5742909) in the promoter region, c.49A $>\mathrm{G}(\mathrm{rs} 231775)$ in exon 1 , and CT60 (g. ${ }^{*} 6230 \mathrm{G}>\mathrm{A}, \mathrm{rs} 3087243$ ) in the $3^{\prime} \mathrm{UTR}$ of the CTLA-4 gene were examined by PCR-restriction fragment length polymorphism (PCR-RFLP) using TruI, BseXI, and TailI enzymes (Fermentas, Burlington, Ontario, Canada). The conditions for digestion with the restriction enzymes are listed in Table 3. The Jo31 (g.*10223G > T; rs11571302) polymorphism in the $3^{\prime}$ UTR region of the CTLA-4 gene was genotyped using PCR followed by single-nucleotide primer extension reactions with dideoxy-NTPs labeled with different fluorochromes corresponding to each allele (SNaPshot Multiplex kit, Applied Biosystems, Warrington, UK). The CTLA-4 g.*642AT(8_33) polymorphism in 3'UTR containing an (AT)n repeat was amplified with the pair of primers where the $5^{\prime}$ end of the forward primers was labeled with JOE (Bionovo, Legnica, Poland). Genotyping was performed in a mixture of amplified products with the internal size standard Gene Scan-350 ROX Size Standard (Applied Biosystems, Foster City, CA,

Table 1 Assessment of severity of Graves' ophthalmopathy according to Baralena et al. $(26,27)$.

\begin{tabular}{|c|c|c|c|}
\hline \multirow[b]{2}{*}{$\begin{array}{l}\text { Degree of } \\
\text { involvement }\end{array}$} & \multicolumn{3}{|c|}{ Parameter } \\
\hline & $\begin{array}{l}\text { Proptosis } \\
\text { (mm) }\end{array}$ & Diplopia & Optic neuropathy \\
\hline Mild & $19-20$ & Intermittent & Subclinical \\
\hline Moderate & $21-23$ & Inconstant & Visual acuity $8 / 10-5 / 10$ \\
\hline Marked & $>23$ & Constant & Visual acuity $<5 / 10$ \\
\hline
\end{tabular}

Severe ophthalmopathy: at least one marked, or two moderate, or one moderate and two mild manifestations. 
Table 2 Clinical and hormonal characteristics of patients with different stages of Graves' ophthalmopathy (GO) severity.

\begin{tabular}{|c|c|c|c|}
\hline & Nonsevere GO & Severe GO & $P$ value \\
\hline Number of cases & 42 & 51 & \\
\hline Age (range) & $49.0(20-82)$ & $50.5(21-78)$ & \\
\hline Female/male & $34 / 8$ & $40 / 11$ & 0.34 \\
\hline $\begin{array}{l}\text { Smoking/ } \\
\text { nonsmoking }\end{array}$ & $20 / 22$ & $31 / 20$ & 0.14 \\
\hline \multicolumn{4}{|l|}{$\mathrm{fT}_{4}(\mathrm{pmol} / \mathrm{l})$} \\
\hline $\begin{array}{l}\text { Mean } \pm \text { S.D. } \\
\text { Median }\end{array}$ & $\begin{array}{c}20.05 \pm 14.69 \\
15.7\end{array}$ & $\begin{array}{c}17.78 \pm 14.64 \\
12.6\end{array}$ & 0.48 \\
\hline \multicolumn{4}{|l|}{$\mathrm{fT}_{3}(\mathrm{pmol} / \mathrm{l})$} \\
\hline $\begin{array}{l}\text { Mean } \pm \text { S.D. } \\
\text { Median }\end{array}$ & $\begin{array}{c}11.42 \pm 8.88 \\
9.0\end{array}$ & $\begin{array}{c}10.75 \pm 8.43 \\
6.8\end{array}$ & 0.75 \\
\hline \multicolumn{4}{|l|}{ Orbitopathy index } \\
\hline $\begin{array}{l}\text { Mean } \pm \text { s.D. } \\
\text { Median }\end{array}$ & $\begin{array}{l}4.57 \pm 1.90 \\
5.00\end{array}$ & $\begin{array}{c}8.11 \pm 1.87 \\
9.00\end{array}$ & 0.00 \\
\hline \multicolumn{4}{|l|}{ CAS } \\
\hline $\begin{array}{l}\text { Mean } \pm \text { S.D. } \\
\text { Median }\end{array}$ & $\begin{array}{c}3.00 \pm 1.37 \\
3.00\end{array}$ & $\begin{array}{c}4.17 \pm 0.94 \\
4.00\end{array}$ & 0.032 \\
\hline \multicolumn{4}{|l|}{ TSH } \\
\hline $\begin{array}{l}\text { Mean } \pm \text { S.D. } \\
\text { Median }\end{array}$ & $\begin{array}{c}1.73 \pm 4.33 \\
0.09\end{array}$ & $\begin{array}{c}3.42 \pm 11.23 \\
0.28\end{array}$ & 0.38 \\
\hline \multicolumn{4}{|l|}{ Anti-TPO } \\
\hline $\begin{array}{l}\text { Mean士s.D. } \\
\text { Median }\end{array}$ & $\begin{array}{c}3969.4 \pm 8265.5 \\
1575.5\end{array}$ & $\begin{array}{c}2299.6 \pm 3915.4 \\
879.5\end{array}$ & 0.21 \\
\hline \multicolumn{4}{|l|}{ TG } \\
\hline $\begin{array}{l}\text { Mean } \pm \text { S.D. } \\
\text { Median } \\
\text { ATG }\end{array}$ & $\begin{array}{c}281.2 \pm 430.3 \\
80.5\end{array}$ & $\begin{array}{c}181.1 \pm 315.5 \\
35.4\end{array}$ & 0.2 \\
\hline $\begin{array}{l}\text { Mean } \pm \text { S.D. } \\
\text { Median }\end{array}$ & $\begin{array}{c}131.4 \pm 410.8 \\
13.6\end{array}$ & $\begin{array}{c}620.7 \pm 1571.9 \\
15.8\end{array}$ & 0.17 \\
\hline \multicolumn{4}{|l|}{ TBII } \\
\hline $\begin{array}{l}\text { Mean } \pm \text { S.D. } \\
\text { Median }\end{array}$ & $\begin{array}{c}15.8 \pm 23.5 \\
5.1\end{array}$ & $\begin{array}{c}9.25 \pm 10.07 \\
7.37\end{array}$ & 0.98 \\
\hline
\end{tabular}

$P<0.05$ are in bold.

USA) using an ABI PRISM 310 capillary electrophoresis system. The PCR reaction condition as well as singlenucleotide primer extension reactions and fluorescencebased technique was carried out as described by Suwalska et al. (30). The primers were designed according to the complete CTLA-4 gene sequence derived from the NCBI Sequence Viewer (http://www. ncbi.nlm.nih.gov/).

\section{Assay of sCTLA-4, TSH, fT , $_{4} \mathrm{fT}_{3}$, anti-TPO, and TBII}

Serum sCTLA-4 concentrations in GD patients and control subjects were measured by ELISA using specific reagent kits for human sCTLA-4 (Bender MedSystems $\mathrm{GmbH}$, Vienna, Austria) according to the manufacturer's protocol. This assay has a linear range between 2.0 and $10 \mathrm{ng} / \mathrm{ml}$. Each sample was analyzed in duplicate. The results below the lower range of test are considered as negative with value 0.0.

Serum concentrations of TSH, $\mathrm{fT}_{4}, \mathrm{fT}_{3}$ (Immulite, Diagnostic Products Corporation (DPC), Los Angeles, CA, USA), anti-TPO (Immunotech, Beckman Coulter, Prague, Czech Republic), and TBII (DYNOtest TRAK human, BRAHMS Diagnostica, Berlin, Germany) were measured using commercial kits.

\section{Statistical analysis}

Statistical significance between means of sCTLA-4, $\mathrm{fT}_{3}$, and $\mathrm{fT}_{4}$ for different groups was calculated by one-way ANOVA, alternatively using the Kruskal-Wallis test, when the variances in groups were not homogeneous (the homogeneity of variance was determined by the Bartlett's test) or when the number of cases was too small. Correlations of sCTLA-4 level and clinical parameters were assessed using the Spearman or Pearson correlation coefficient. Association of sCTLA-4 level and the pattern of CTLA-4 gene polymorphisms were assessed using one-way ANOVA, alternatively using the Kruskal-Wallis test. Comparison between groups in regards of an occurrence of a particular parameter was assessed by means of odds ratio (OR). A $P$ value of $<0.05$ was considered significant. Statistical analyses were made using the EPIINFO Version 3.3.2 program (version 09-02-2005).

\section{Results}

Serum sCTLA-4 concentrations were measurable in $77.4 \%(72 / 93)$ of the samples taken from the GD patients and in $45.2 \%(42 / 93)$ of the samples from the healthy subjects (odds ratio $(\mathrm{OR})=3.82,95 \%$ confidence interval (CI): 2.03-7.20, $P<0.00001)$. Serum sCTLA-4 concentrations were significantly higher in the GD subjects compared with the controls (median: 7.94 vs $0.00 \mathrm{ng} / \mathrm{ml}, P=0.000001$; Fig. 1 ).

An increased level of SCTLA-4 was found in the patients with severe GO compared with the controls (median: 10.3 vs $0.00 \mathrm{ng} / \mathrm{ml}, P=0.000001$ ) and in

Table 3 Conditions for PCR product digestion with restriction enzymes.

\begin{tabular}{|c|c|c|c|c|}
\hline Amplicon (bp) & SNP & Enzyme & $\begin{array}{l}\text { Temperature and } \\
\text { duration of digestion }\end{array}$ & $\begin{array}{l}\text { Products of digestion } \\
\text { visible on gel }(b p)\end{array}$ \\
\hline 814 & $C T L A-4 \mathrm{~g} \cdot 319 \mathrm{C}>\mathrm{T}$ & Trul (Msel) & $65^{\circ} \mathrm{C}, 4 \mathrm{~h}$ & $\begin{array}{l}\text { C: } 51,101,100,562 \\
\text { T: } 51,101,100,94,468\end{array}$ \\
\hline 814 & $C T L A-4 \mathrm{c} .49 \mathrm{~A}>\mathrm{G}$ & BseXI (Bbvl) & $65^{\circ} \mathrm{C}, 4 \mathrm{~h}$ & $\begin{array}{l}\text { A: } 207,607 \\
\text { G: } 207,508,99\end{array}$ \\
\hline 806 & CT60G $>A$ & Taill (Msell) & $65^{\circ} \mathrm{C}, 4 \mathrm{~h}$ & $\begin{array}{l}\mathrm{G}: 419,236,151 \\
\mathrm{~A}: 236,570\end{array}$ \\
\hline
\end{tabular}




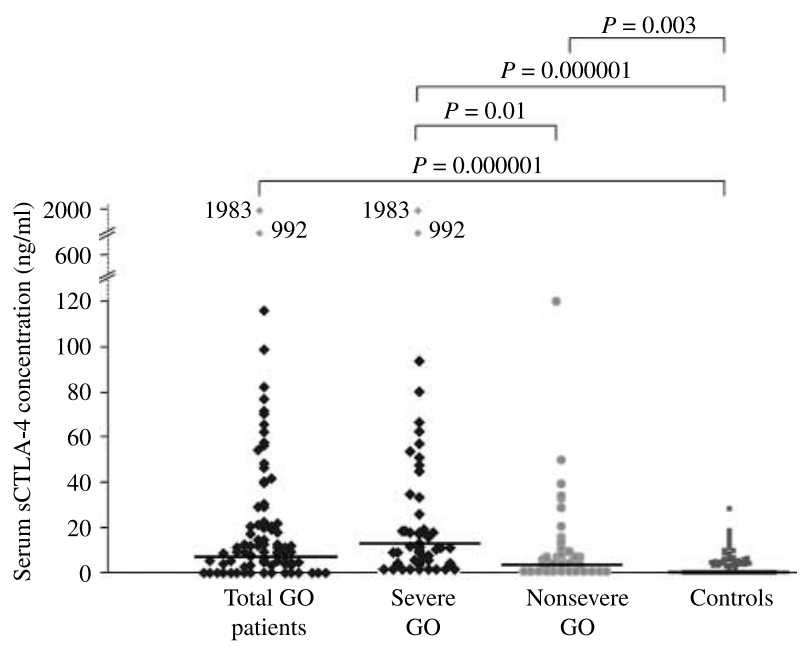

Figure $1 \mathrm{~A}$ soluble form of CTLA-4 in serum of patients with GD, patients with severe Graves' ophthalmopathy (s GO), nonsevere GO (ns GO), and controls (thick horizontal line - median).

the patients with nonsevere GO (median: 10.3 vs $5.6 \mathrm{ng} / \mathrm{ml}, P=0.01$; Fig. 1).

Values higher than the mean plus doubled S.D. of the control serum samples $(16.62 \mathrm{ng} / \mathrm{ml})$ were considered to be substantially elevated in this study. Elevated sCTLA-4 levels were noted in $31.2 \%$ (29/93) of all GD patients. The elevated soluble isoform of CTLA-4 was more frequently observed in the group of patients with severe symptoms of GO $(41.2 \%, 21 / 51)$, while only in $19 \%(8 / 42)$ patients with nonsevere GO $(\mathrm{OR}=2.98$, 95\% CI: $1.15-7.70, P<0.02)$. By contrast, in the control group, elevated sCTLA-4 level was observed only in six persons.

We did not observe any correlation of the ophthalmopathy index and CAS, parameters reflecting the clinical expression of GO, with sCTLA-4 levels $(r=0.15$, $P=0.16 ; r=0.08 P=0.46$ respectively). There was no correlation between sCTLA-4 and thyroid hormone levels $\left(\mathrm{fT}_{4}\right.$ and $\left.\mathrm{fT}_{3}\right)(r=-0.08, P=0.48 ; r=-0.13$, $P=0.29$ respectively), while sCTLA-4 serum level tended to be associated with thyroid status $(r=0.21$, $P=0.06$ ). sCTLA-4 level was independent of gender $(P=0.92)$, positive familial history for thyroid diseases $(P=0.27)$, and smoking status $(P=0.58)$. Finally, there was no correlation between thyroid autoantibodies (anti-TPO, anti-Tg, TBII) and sCTLA-4 concentration $(P=0.60, P=0.48$, and $P=0.39$ respectively).

The study of an association of the CTLA-4 gene polymorphisms: g.319C $>$ T, c.49A $>$ G, CT60, Jo31,

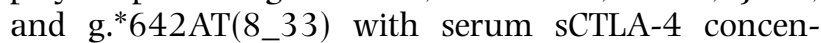
tration showed a link between Jo31 and CT60 polymorphic variants and serum sCTLA-4 level. Patients possessing Jo31[G] allele (genotype GG+GT, 74/92) had elevated serum sCTLA-4 compared with subjects with a lack of the $[\mathrm{G}]$ allele (carriers of the TT genotype, $18 / 92$; median: $9.18 \mathrm{vs} 4.0 \mathrm{ng} / \mathrm{ml}, P=0.02$;
Table 4, Fig. 2). Elevated serum sCTLA-4 was observed in carriers of CT60[G] allele (genotype GG + GA, 81/93) compared with subjects with an absence of the $\mathrm{G}$ allele (carriers of the AA genotype, 12/93; median: $8.73 \mathrm{vs}$ $2.28 \mathrm{ng} / \mathrm{ml}, P=0.03$; Table 4, Fig. 2). Moreover, carriers of [G] allele at both polymorphic sites CT60 and Jo31 (72/93, 77.4\%) have significantly higher serum SCTLA-4 level than patients double-homozygous Jo31[TT]\&CT60[AA] (11/93, 11.8\%; median: 9.32 vs $1.39 \mathrm{ng} / \mathrm{ml}, \quad P=0.01$ ). We also noted a significant difference between the level of sCTLA-4 in sera in patients double [GG] homozygous at studied polymorphic sites $(34 / 93,36.6 \%)$ in comparison with counter partners $[\mathrm{AA}] \&[\mathrm{TT}](11 / 93,11.8 \%$; median: 7.35 vs $1.39 \mathrm{ng} / \mathrm{ml}, P=0.02$ ). The other CTLA-4 gene polymorphisms studied were not related to serum sCTLA-4 levels (Table 4).

\section{Discussion}

GD is a common autoimmune disorder of the thyroid in which stimulatory antibodies bind to the TSH receptor and activate glandular function, resulting in hyperthyroidism.

In the present study, we observed significantly increased serum sCTLA-4 levels in GD patients compared with controls. It should be noted that despite using a commercial kit with possibly less sensitivity than in very initial studies (10), the presence of the SCTLA-4 molecule was found in a vast majority of the study and in nearly half of the control group. Our results are in agreement with those of Oaks \& Hallet (11), and Saverino et al. (13) performed in much smaller groups of subjects.

Since there is a need to find a biochemical parameter with the power to recognize the active phase of GO or identify GD patients at risk of severe eye symptoms, we

Table 4 Effect of CTLA-4 gene polymorphism variant on SCTLA-4 levels in Graves' disease patients.

\begin{tabular}{|c|c|c|c|}
\hline $\begin{array}{l}\text { Polymorphic } \\
\text { site }\end{array}$ & Genotype & $\begin{array}{c}\text { sCTLA-4 } \\
(\mathrm{ng} / \mathrm{ml})\end{array}$ & $P$ value \\
\hline g.319C $>$ T & $\begin{array}{l}\mathrm{AA}+\mathrm{CT} \\
\mathrm{CC}\end{array}$ & $\begin{array}{r}11.58 \\
7.76\end{array}$ & 0.08 \\
\hline c. $49 \mathrm{~A}>\mathrm{G}$ & $\begin{array}{l}\mathrm{GG}+\mathrm{AG} \\
\mathrm{AA}\end{array}$ & $\begin{array}{l}9.12 \\
8.15\end{array}$ & 0.55 \\
\hline Jo31 & $\begin{array}{l}\mathrm{GG}+\mathrm{GT} \\
\mathrm{TT}\end{array}$ & $\begin{array}{l}9.80 \\
4.00\end{array}$ & 0.02 \\
\hline CT60 & $\begin{array}{l}\mathrm{GG}+\mathrm{GA} \\
\mathrm{AA}\end{array}$ & $\begin{array}{l}8.73 \\
2.28\end{array}$ & 0.03 \\
\hline g. ${ }^{*} 642 A T\left(8 \_33\right)$ & $\begin{array}{l}(\text { AT })>8 /(\text { AT })>8 \\
+(\text { AT })>8 /(\text { AT }) 8 \\
(\text { AT }) 8 /(\text { AT }) 8\end{array}$ & $\begin{array}{l}8.39 \\
7.60\end{array}$ & 0.12 \\
\hline Jo31/CT60 & $\begin{array}{l}(G G+G T) \&(G G+G A) \\
T T \& A A\end{array}$ & $\begin{array}{l}9.32 \\
1.39\end{array}$ & 0.01 \\
\hline Jo31/CT60 & $\begin{array}{l}\text { GG\&GG } \\
\text { TT\&AA }\end{array}$ & $\begin{array}{l}7.35 \\
1.39\end{array}$ & 0.02 \\
\hline
\end{tabular}

$P<0.05$ are marked in bold. 


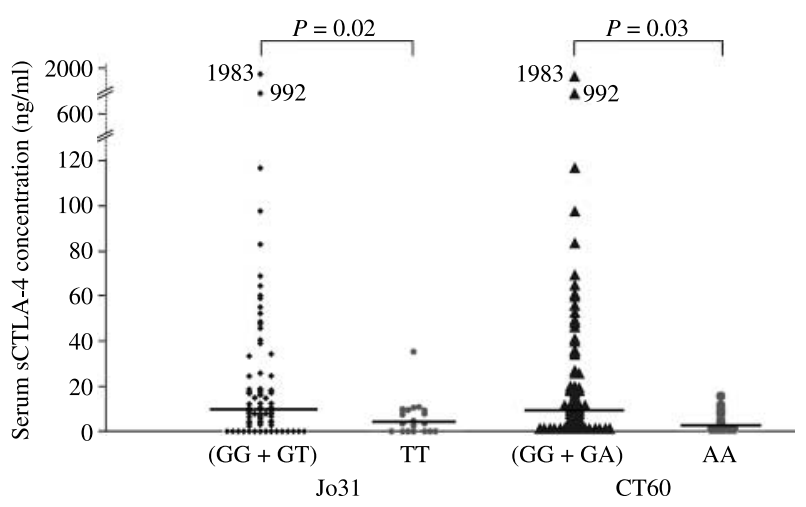

Figure 2 A soluble form of CTLA-4 in serum of patients with phenotypic variants of Jo31 and CT60 polymorphic sites in the $3^{\prime}$ UTR region of CTLA-4 gene in group of GD patients (thick horizontal line - median).

also analyzed sCTLA-4 in patients with different stages of GO. We found an association of sCTLA-4 concentrations with GO status, as patients with severe GO had statistically higher sCTLA-4 levels than both controls and patients with nonsevere eye symptoms. It is worth noting that the high sCTLA-4 level was observed significantly more often in patients with severe GO than in the nonsevere group. Saverino et al. reported no relationship between sCTLA-4 level and severity of GO (13). However, this observation was based on data from a small group of 31 patients.

There was no link between sCTLA-4 concentration and clinical symptoms of active GO. Studies of correlations of sCTLA-4 levels with disease activity in other autoimmune diseases gave inconsistent results. sCTLA-4 was found to correlate with autoantibodies against nicotinic acetylcholine receptors in myasthenia gravis (21) and area of skin lesions and severity of index values in psoriasis vulgaris (24), but not with disease activity in systemic lupus erythematosus (15). Our observations refute a potential utility of sCTLA-4 as a biochemical marker of ocular change activity, but may testify in favor of a predominantly genetic over an environmental regulation of SCTLA- 4 synthesis. It has been hypothesized that increased sCTLA-4 levels in autoimmune thyroid disease are related more to genetic than to environmental factors $(11,31)$.

There was no association between thyroid function and serum sCTLA-4 level, as was reported also by others (13). No relationships between sCTLA-4 concentration and factors known to aggravate GO, such as smoking habit (32), age, and gender (33), were found in our study, similarly to Saverino et al. (13). The different sex ratio in GO subjects and control group does not seem to influence results of SCTLA- 4 estimation and comparison since the molecule level did not differ between both genders.

The influence of the polymorphisms within CTLA-4 gene on the GD $(31,34-42)$ as well as on GO (43-45) has been widely studied. The CT60 in the 3'UTR region of this gene was the most promising locus for the autoimmune thyroid disease $(31,40-42)$. Notwithstanding, the present study has been focused on the possible influence of tested polymorphic sites on the serum sCTLA-4 concentration.

We found a significant correlation of the two SNPs in 3'UTR of the CTLA-4 gene, which were shown to be in strong linkage disequilibrium (32), and levels of soluble isoform of CTLA-4 protein. We observed for the first time a statistically higher serum sCTLA-4 concentration in patients possessing the Jo31[G] allele (genotype GG+ GT) than in patients possessing the [TT] genotype. Moreover, carriers of CT60[G] allele (genotype GG + GA) also had higher sCTLA-4 levels in serum than other patients. In contrast, others $(20,25)$ did not observe any relation between CT60 polymorphism and serum sCTLA-4 level. We did not report any significant correlation of other CTLA-4 gene polymorphisms studied with sCTLA-4 level in serum; however, we noted that promoter polymorphism (g.319C $>\mathrm{T}$ ) tended to be associated with higher sCTLA-4 levels. On the contrary, no association of this polymorphism in SLE patients (15) and in psoriasis vulgaris (22) was found. Similarly to us, Łuszczek et al. (22) failed to find an association of c. $49 \mathrm{~A}>\mathrm{G}$ and sCTLA-4 serum level in psoriasis vulgaris, while the latest study in type 1 diabetes suggests a possible gene dosage effect for the concentrations of sCTLA-4 among the different c.49A $>\mathrm{G}$ genotypes of CTLA-4 (25). Wang et al. also did not observe any association between the g.*642AT(8_33) polymorphism in the $3^{\prime}$ UTR and sCTLA-4 level in myasthenia gravis (21). We have provided preliminary data to support the hypothesis that the Jo31[G] and CT60[G] alleles influence the concentrations of SCTLA-4.

The results of the present study may suggest that the ability to produce SCTLA-4 is under genetic control and that after immune activation individuals possessing [G] allele at position Jo31 and CT60 are eager producers of sCTLA-4. If this should turn out to be true, our finding of higher sCTLA-4 levels in severe GO subjects could imply therapeutic consequences. It would suggest a need for an especially careful follow-up of GD patients with high sCTLA-4 levels regarding eye symptoms, including a tight metabolic control of hormonal disturbances, avoidance of harmful environmental factors, as well as early immunosuppressive treatment of GO. This idea must be strengthened by studies on longitudinal measurements of sCTLA-4 serum concentration at different stages of GD and by setting a threshold serum sCTLA-4 level with a sufficient specificity.

To summarize, our study revealed that serum sCTLA-4 concentration seems to be more genetically determined than influenced by environmental or hormonal factors and appears to be related to the severity of eye changes. Serum sCTLA-4 level might be considered a useful biochemical marker of the occurrence of severe GO. 


\section{Declaration of interest}

The authors declare that there is no conflict of interest that could be perceived as prejudicing the impartiality of the research reported.

\section{Funding}

The study was supported by funds from the Polish Scientific Research Committee (No. 2PO5B 05529 and No. 1263).

\section{References}

1 Weetman AP. Autoimmune thyroid disease. Autoimmunity 2004 37 337-340.

2 Prabhakar BS, Bahn RS \& Smith TJ. Current perspective on the pathogenesis of Graves' disease and ophthalmopathy. Endocrine Reviews 200324 802-835.

3 Weetman AP \& McGregor AM. Autoimmune thyroid disease: further developments in our understanding. Endocrine Reviews $199415788-830$

4 Heward J \& Gough SC. Genetic susceptibility to the development of autoimmune disease. Clinical Science 199793 479-491.

5 Tomer Y \& Davies TF. Searching for the autoimmune thyroid disease susceptibility genes: from gene mapping to gene function. Endocrine Reviews 200324 694-717.

6 Philippou G \& McGregor AM. The aetiology of Graves' disease: what is the genetic contribution? Clinical Endocrinology $1998 \mathbf{4 8}$ 393-395.

7 Chang TT, Kuchroo VK \& Sharpe AH. Role of the B7-CD28/ CTLA-4 pathway in autoimmune disease. Current Directions in Autoimmunity 20025 113-130.

8 Krummel MF \& Allison JP. CD28 and CTLA-4 have opposing effects on response of $\mathrm{T}$ cells to stimulation. Journal of Experimental Medicine 1995182 459-465.

9 Kosmaczewska A, Ciszak L, Bocko D \& Frydecka I. Expression and functional significance of CTLA-4, a negative regulator of T cell activation. Archivum Immunologiae et Therapiae Experimentalis 200149 39-46.

10 Magistrelli G, Jeannin P, Herbault N, Benoit De CA, Gauchat JF, Bonnefoy JY \& Delneste Y. A soluble form of CTLA-4 generated by alternative splicing is expressed by nonstimulated human $\mathrm{T}$ cells. European Journal of Immunology 199929 3596-3602.

11 Oaks MK \& Hallett KM. Cutting edge: a soluble form of CTLA-4 in patients with autoimmune thyroid disease. Journal of Immunology $20001645015-5018$.

12 Oaks MK, Hallett KM, Penwell RT, Stauber EC, Warren SJ \& Tector AJ. A native soluble form of CTLA-4. Cellular Immunology 2000201 144-153.

13 Saverino D, Brizzolara R, Simone R, Chiappori A, MilintendaFloriani F, Pesce G \& Bagnasco M. Soluble CTLA-4 in autoimmune thyroid diseases: relationship with clinical status and possible role in the immune response dysregulation. Clinical Immunology 2007 123 190-198.

14 Pawlak E, Kochanowska IE, Frydecka I, Kielbinski M, Potoczek S \& Bilinska M. The soluble CTLA-4 receptor: a new marker in autoimmune diseases. Archivum Immunologiae et Therapiae Experimentalis $2005 \mathbf{5 3} 336-341$.

15 Liu MF, Wang CR, Chen PC \& Fung LL. Increased expression of soluble cytotoxic T-lymphocyte-associated antigen-4 molecule in patients with systemic lupus erythematosus. Scandinavian Journal of Immunology 200357 568-572.

16 Sato S, Fujimoto M, Hasegawa M, Komura K, Yanaba K, Hayakawa I, Matsushita T \& Takehara K. Serum soluble CTLA-4 levels are increased in diffuse cutaneous systemic sclerosis. Rheumatology 200443 1261-1266.

17 Pawlak E, Bilinska M, Suwalska K, Tutak A, Kosmaczewska A, Ciszak L \& Frydecka I. Serum soluble CTLA-4 (sCTLA-4) levels in patients with multiple sclerosis. Polish Journal of Environmental Studies 200514 1261-1266.
18 Purohit S, Podolsky R, Collins C, Zheng W, Schatz D, Muir A, Hopkins D, Huang YH \& She JX. Lack of correlation between the levels of soluble cytotoxic T-lymphocyte associated antigen-4 (CTLA-4) and the CT-60 genotypes. Journal of Autoimmune Diseases 200528.

19 Mayans S, Lackovic K, Nyholm C, Lindgren P, Ruikka K, Eliasson M, Cilio CM \& Holmberg D. CT60 genotype does not affect CTLA-4 isoform expression despite association to T1D and AITD in northern Sweden. BMC Medical Genetics 200783.

20 Momin S, Flores S, Angel BB, Codner DE, Carrasco PE \& Perez-Bravo F. Interactions between programmed death 1 (PD-1) and cytotoxic T lymphocyte antigen 4 (CTLA-4) gene polymorphisms in type 1 diabetes. Diabetes Research and Clinical Practice 2009 83 289-294.

21 Wang XB, Kakoulidou M, Giscombe R, Qiu Q, Huang D, Pirskanen R \& Lefvert AK. Abnormal expression of CTLA-4 by T cells from patients with myasthenia gravis: effect of an AT-rich gene sequence. Journal of Neuroimmunology $2002130224-232$.

$22 \mathrm{Gu} \mathrm{M}$, Kakoulidou M, Giscombe R, Pirskanen R, Lefvert AK, Klareskog L \& Lefvert AK. Identification of CTLA-4 isoforms produced by alternative splicing and their association with myasthenia gravis. Clinical Immunology 2008128 374-381.

23 Li X, Xiao BG, Lu CZ \& Lu JH. Decrease of CD4+CD25highFoxp $3+$ regulatory $\mathrm{T}$ cells and elevation of Cd19+BAFF-R $+\mathrm{B}$ cells and soluble ICAM-1 in myasthenia gravis. Clinical Immunology 2008126 180-188.

24 Luszczek W, Kubicka W, Jasek M, Baran E, Cislo M, Nockowski P, Luczywo-Rudy M, Wisniewski A, Nowak I \& Kusnierczyk P. CTLA-4 gene polymorphisms and natural soluble CTLA-4 protein in psoriasis vulgaris. International Journal of Immunogenetics 2006 33 217-224.

25 Berry A, Tector M \& Oaks MK. Lack of association between sCTLA-4 levels in human plasma and common CTLA-4 polymorphisms. Journal of Negative Results in Biomedicine 200878

26 Bartalena L, Marcocci C, Bogazzi F, Manetti L, Tanda ML, Dell'Unto E, Bruno-Bossio G, Nardi M, Bartolomei MP, Lepri A, Rossi G, Martino E \& Pinchera A. Relation between therapy for hyperthyroidism and the course of Graves' ophthalmopathy. New England Journal of Medicine 1998338 73-78.

27 Marcocci C, Bartalena L, Tanda ML, Manetti L, Dell'Unto E, Rocchi R, Barbesino G, Mazzi B, Bartolomei MP, Lepri P, Cartei F, Nardi M \& Pinchera A. Comparison of the effectiveness and tolerability of intravenous or oral glucocorticoids associated with orbital radiotherapy in the management of severe Graves' ophthalmopathy: results of a prospective, single-blind, randomized study. Journal of Clinical Endocrinology and Metabolism 200186 3562-3567.

28 Pinchera A, Wiersinga W, Glinoer D, Kendall-Taylor P, Koornneef L, Marcocci C, Schleusensr H, Romaldi J, Niepominiszcze H, Negataki S, Izumi M, Inoune Y, Stockigt J, Wall J, Greenspan F, Solomon D, Garrity J \& Gorman CA. Classification of eye changes of Grave's disease. Thyroid 19922 235-236.

29 Mourits MP, Koornneef L, Wiersinga WM, Prummel MF, Berghout A \& van der Gaag R. Clinical criteria for the assessment of disease activity in Graves' ophthalmopathy: a novel approach British Journal of Ophthalmology 198973 639-644.

30 Suwalska K, Pawlak E, Karabon L, Tomkiewicz A, Dobosz T, Urbaniak-Kujda D, Kuliczkowski K, Wolowiec D, Jedynak A \& Frydecka I. Association studies of CTLA-4, CD28, and ICOS gene polymorphisms with B-cell chronic lymphocytic leukemia in the Polish population. Human Immunology 200869 193-201.

31 Ueda H, Howson JM, Esposito L, Heward J, Snook H, Chamberlain G, Rainbow DB, Hunter KM, Smith AN, Di GG, Herr MH, Dahlman I, Payne F, Smyth D, Lowe C, Twells RC, Howlett S, Healy B, Nutland S, Rance HE, Everett V, Smink LJ, Lam AC, Cordell HJ, Walker NM, Bordin C, Hulme J, Motzo C, Cucca F, Hess JF, Metzker ML, Rogers J, Gregory S, Allahabadia A, Nithiyananthan R, Tuomilehto-Wolf E, Tuomilehto J, Bingley P, Gillespie KM, Undlien DE, Ronningen KS, Guja C, IonescuTirgoviste C, Savage DA, Maxwell AP, Carson DJ, Patterson CC, 
Franklyn JA, Clayton DG, Peterson LB, Wicker LS, Todd JA \& Gough SC. Association of the T-cell regulatory gene CTLA4 with susceptibility to autoimmune disease. Nature $2003 \mathbf{4 2 3} 506-510$.

32 Bartalena L, Martino E, Marcocci C, Bogazzi F, Panicucci M, Velluzzi F, Loviselli A \& Pinchera A. More on smoking habits and Graves' ophthalmopathy. Journal of Endocrinological Investigation $198912733-737$.

33 Perros P, Crombie AL, Matthews JN \& Kendall-Taylor P. Age and gender influence the severity of thyroid-associated ophthalmopathy: a study of 101 patients attending a combined thyroid-eye clinic. Clinical Endocrinology 199338 367-372.

34 Kavvoura FK, Akamizu T, Awata T, Ban Y, Chistiakov DA, Frydecka I, Ghaderi A, Gough SC, Hiromatsu Y, Ploski R, Wang PW, Ban Y, Bednarczuk T, Chistiakova EI, Chojm M, Heward JM, Hiratani H, Juo SH, Karabon L, Katayama S, Kurihara S, Liu RT, Miyake I, Omrani GH, Pawlak E, Taniyama M, Tozaki T \& Ioannidis JP. CTLA-4 gene polymorphisms and autoimmune thyroid disease: a meta analysis. Journal of Clinical Endocrinology and Metabolism 200792 3162-3170.

35 Ban Y, Concepcion ES, Villanueva RB, Greenberg DA, Davies TF \& Tomer Y. Analysis of immune regulatory genes in familial and sporadic Graves' disease. Journal of Clinical Endocrinology and Metabolism $2004894562-4568$.

36 Kouki T, Sawai Y, Gardine CA, Fisfalen ME, Alegre ML \& DeGroot LJ. CTLA-4 gene polymorphism at position 49 in exon 1 reduces the inhibitory function of CTLA- 4 and contributes to the pathogenesis of Graves' disease. Journal of Immunology 2000165 6606-6611.

37 Takara M, Kouki T \& DeGroot LJ. CTLA-4 AT-repeat polymorphism reduces the inhibitory function of CTLA-4 in Graves' disease. Thyroid 200313 1083-1089.

38 Yanagawa T, Hidaka Y, Guimaraes V, Soliman M \& DeGroot LJ CTLA-4 gene polymorphism associated with Graves' disease in a Caucasian population. Journal of Clinical Endocrinology and Metabolism $19958041-45$.
39 Kouki T, Gardine CA, Yanagawa T \& Degroot LJ. Relation of three polymorphisms of the CTLA-4 gene in patients with Graves' disease. Journal of Endocrinological Investigation 200225 208-213.

40 Petrone A, Giorgi G, Galgani A, Alemanno I, Corsello SM, Signore A, Di Mario U, Nistico L, Cascino I \& Buzzetti R. CT60 single nucleotide polymorphisms of the cytotoxic T-lymphocyteassociated antigen- 4 gene region is associated with Graves' disease in an Italian population. Thyroid $200515232-238$.

41 Ban Y, Tozaki T, Taniyama M, Tomita M \& Ban Y. Association of a CTLA-4 3' untranslated region (CT60) single nucleotide polymorphism with autoimmune thyroid disease in the Japanese population. Autoimmunity 200538 151-153.

42 Weng YC, Wu MJ \& Lin WS. CT60 single nucleotide polymorphism of the CTLA_4 gene is associated with susceptibility to Graves' disease in the Taiwanese population. Annals of Clinical and Laboratory Science 200535 259-262.

43 Bednarczuk T, Gopinath B, Ploski R \& Wall JR. Susceptibility genes in Graves' ophthalmopathy: searching for a needle in a haystack? Clinical Endocrinology 200767 3-19.

44 Frydecka I, Daroszewski J, Suwalska K, Zoledziowska M, Tutak A, Slowik M, Potoczek S \& Dobosz T. CTLA-4 (CD152) gene polymorphism at position 49 in exon 1 in Graves' disease in a Polish population of the Lower Silesian region. Archivum Immunologiae et Therapiae Experimentalis 200452 369-374.

45 Han S, Zhang S, Zhang W, Li R, Li Y, Wang Z, Xie Y \& Mao Y. CTLA4 polymorphisms and ophthalmopathy in Graves' disease patients: association study and meat-analysis. Human Immunology $200667618-626$.

Received 27 August 2009

Accepted 31 August 2009 